OSOBA | WARTOŚCI

Filozofia ChrześciJańsKa • Tom 8, Poznań 2011

Uniwersytet im. Adama Mickiewicza • Wydziat Teologiczny

WALDEMAR KMIECIKOWSKI

\title{
Niepewność - zasadnicza kategoria etyczno-antropologiczna w refleksji Zygmunta Baumana
}

\author{
Uncertainty - Zygmunt Bauman's Basic Ethical-Anthropological Category
}

W naszych analizach podejmiemy próbę zrekonstruowania kilku znaczących momentów refleksji Zygmunta Baumana koncentrującej się na problematyce etycznej i antropologicznej. Bogata spuścizna polskiego postmodernisty zasługuje niewątpliwie na to, aby dokonać wglądu w jej zawartość. Wydaje się, że - pomimo dominacji socjologicznego paradygmatu Baumanowskiej analizy - można odnaleźć w niej znaczące motywy fillozoficzne. Spróbujemy dokonać ich eksplikacji, a jednocześnie umieścimy je na tle zasadniczej - jak sądzimy - etyczno-antropologicznej kategorii, jaką jest niepewność. Przekonani, że myśl Baumana przeniknięta jest motywem niepewności, skoncentrujemy się na kilku jej przejawach i finalnie spróbujemy także ją odnieść do ontologicznych założeń, które implicite zdają się być obecne w Baumanowskich badaniach.

\section{NIEPEWNOŚĆ NA POZIOMIE GLOBALNYM}

Charakterystyczne dla Baumana jest osadzenie jednostkowej niepewności w kontekście globalnym. To ów kontekst zdaje się nadawać oryginalne, indywidualne znamię Baumanowskim rozważaniom. Niepewność bowiem w optyce filozofa nie stanowi ani akcydentalnego rysu towarzyszącego pewnemu etapowi życia człowieka (który poszukuje własnej tożsamości) - i jako taka byłaby przejściowa - ani też nie jest ograniczona do pewnej grupy osób. 
W ujęciu Baumana niepewność okazuje się być immanentnym, istotnym momentem egzystencji współczesnego człowieka, której nie da się już wyizolować z globalnej całości; całości, która wywiera wpływ na istnienie pojedynczego człowieka i temuż wpływowi podlega. Wszakże ,cokolwiek się dzieje w jakimkolwiek miejscu - twierdzi Bauman - wpływa na to, jak żyją ludzie we wszystkich innych miejscach, jak mają nadzieję żyć i jak oczekują, że będą żyć [...]. Nic nie jest, bądź nie może na długo pozostać neutralne i obojętne wobec czegokolwiek innego" ; wszakże „,na negatywnie zglobalizowanej planecie wszystkie najbardziej fundamentalne problemy [...] są globalne i jako takie pozostają odporne na wszelkie lokalne rozwiązania [...]"2; i jak polski postmodernista w innym miejscu zauważy - ,z punktu widzenia ofiar jednostronna globalizacja, ograniczona do biznesu, oznacza przede wszystkim utratę kontroli nad dniem dzisiejszym i niezdolność przewidzenia tego, co może przynieść przyszłość, a więc także niezdolność opracowania sposobów radzenia sobie z przyszłością"3.

Niepewność okazuje się więc wpisana niejako w naturę współczesnego człowieczego bycia. Skoro nie istnieją już żadne enklawy suwerennego - autonomicznego wobec sieci globalnych zależności i skutków obecności owych powiązań - ludzkiego bytowania; skoro pojedynczy człowiek zdaje się być wtopiony we współczesną zglobalizowaną rzeczywistość, to wszelkie negatywne przejawy tejże globalizacji zdają się dotykać każdą ludzką jednostkę. Ta ostatnia jawi się jako nieuchronnie uwikłana w kontekst terroryzmu, utraty pracy, niepewności odnośnie do możliwości utrzymania rodziny itp. W optyce Baumana niepewność stanowiąca nieusuwalne wręcz znamię globalizacji i posiada wymiar ogólnoludzki. Przecież ,globalizacja to, co się dzieje z nami wszystkimi”4, a „immanentną częścią procesu globalizacji jest postępująca segregacja przestrzenna, separacja oraz wykluczenie"5.

Współczesny, ponowoczesny czy - używając innego sformułowania Baumana - czlowiek płynnej nowoczesności jest przeniknięty negatywnymi skutkami owej globalizacji. W ujęciu Baumana rzeczywistość, w której dokonuje się ludzka egzystencja, rodzi trwałą i wielokształtną niepewność. Filozof powie, że „ekonomika, przemoc, gwałt są już dziś zaiste globalne, ale polityka, a zatem i nasze poczynania zbiorowe nie wychodza jak dawniej poza krajowe opłotki i gdzie im tam do zmierzenia się ze światowym biznesem i solda-

\footnotetext{
${ }^{1}$ Z. Bauman, Plynne czasy. Życie w epoce niepewności, Warszawa 2007, s. 14.

${ }^{2}$ Tamże, s. 39.

${ }^{3}$ Tenże, Ptynne życie, Kraków 2007, s. 234.

${ }^{4}$ Tenże, Globalizacja. I co z tego dla ludzi wynika, Warszawa 2000, s. 72.

${ }^{5}$ Tamże, s. 7.
} 
teską [...]"'. Struktury państwowe doby dzisiejszej stają się bezradne wobec globalizacji i jej destrukcyjnych dla egzystencji pojedynczego człowieka skutków. Państwo zdaje się nie nadążać za tempem planetarnych zmian, które wyłamują się spod państwowej kontroli. Wiele elementów dawniej - w okresie twardej nowoczesności poprzedzającej współczesną ponowoczesność przynależnych do prerogatyw państwa dzisiaj ulega prywatyzacji i deregula$c j i^{7}$. Człowiek ponowoczesny zostaje pozostawiony sam sobie - zostaje obciążony koniecznością rozwiązywania problemów, które wczorajsze (zanikające) państwo narodowe samo usiłowało rozwiązywać, np. problemy mieszczące się w kontekście opieki społecznej, zabezpieczenia społecznego, ograniczania bezrobocia czy edukacyjnego przygotowania do sprostania oczekiwaniom rynku pracy.

Znamienite dla filozofa jest to, że niepewność w dobie globalizacji nie ogranicza się tylko do osób żyjących w regionach ubogich, lecz zdaje się dotykać każdego człowieka. Musimy bliżej przyjrzeć się temu aspektowi rozważań filozofa.

\section{NIEPEWNOŚĆ INDYWIDUALNA}

Człowiek żyjący w stanie komfortu psychicznego związanego z możliwością zabezpieczenia szeregu potrzeb także jest wtopiony w horyzont fundamentalnej, ponowoczesnej niepewności. Ów horyzont wypełniony jest przez różnorodne elementy. Odnajdujemy wśród nich strach przed obcymi, który skutkuje budowaniem miejskich, współczesnych twierdz (osiedli i budynków) oddzielających zamożną część społeczeństwa przed groźnymi, nieznanymi Innymi, jak również specyficzne, ukradkowe spojrzenie kierowane na mijanych przechodniów; spojrzenie ,jakie przechodzień rzuca spod na wpół przymkniętych powiek na innych przechodniów, nie chcąc przypadkiem zbliżyć się zbytnio, ale i nie chcąc zdradzić się, że się przygląda i zachęcić w ten sposób do zaczepki"». Odnajdujemy także niepewność zawodową. Wszakże „stała, dobrze strzeżona i pewna praca należy dzisiaj do rzadkości. [...]. Sloganem naszych czasów stała się - pisze dalej Bauman - 'elastyczność' i to coraz modniejsze pojęcie oznacza grę w zatrudnianie i zwalnianie przy przestrzeganiu niewielu reguł, zwykle zmienianych jednostronnie podczas owej

\footnotetext{
${ }^{6}$ Tenże, Moralność w niestabilnym świecie, Poznań 2006, s. 16.

${ }^{7}$ Por. tenże, Szanse etyki w zglobalizowanym świecie, Kraków 2007, s. 131n, 139; tenże, Plynne życie, s. 72n., 92n.

${ }^{8}$ Tenże, Etyka ponowoczesna, Warszawa 1996, s. 208. Por. tenże, Plynne życie, s. 114nn.
} 
gry". Wśród elementów powyższego horyzontu niepewności napotykamy także obawę przed tym, aby nie stać się kolejną jednostką przynależącą do grona odrzuconych i nieprzystających do współczesnej rzeczywistości. Znamienite jest Baumanowskie określanie tychże odrzuconych jako nowych ubogich. Wedle filozofa bowiem bycie ponowoczesnym ubogim niekoniecznie musi wiązać się z określonym (niskim) statusem materialnym. „Ubóstwo oznacza - konstatuje polski myśliciel - wykluczenie z tego, co określa się jako 'normalne życie'. Oznacza 'niemożność dorównania innym"'10. Trwoga nie tylko przed obcymi (która w warunkach miejskich przechodzi w miksofobię ${ }^{11}$ ), lecz także lęk, iż konkretne „Ja” może zasilić szeregi nieprzystosowanych, a więc i nie nadążających za zmianami współczesnego dziania się posiada charakter zarówno powszechny, jak i dokuczliwy. Bauman zdecydowanie stwierdza, że ,prawdziwą stawką wyścigu jest (tymczasowe) ocalenie przed zasileniem wykluczonych i uniknięcie wywózki na śmietnik"12.

Powstaje oczywiście w tym momencie pytanie, czym jest owo normalne życie, z którego wykluczenie wzbudza powszechny lęk. W optyce Baumanowskiej niewątpliwie owym życiem będzie życie konsumenta. Epoka ponowoczesna przecież to nie epoka wytwórców (którzy w czasach twardej nowoczesności stanowili przedmiot troski etyki pracy ${ }^{13}$ ), lecz właśnie epoka konsumentów. Istotne wszakże dla funkcjonowania współczesnego społeczeństwa nie jest już wytwarzanie, ale konsumowanie wytworzonych produktów. O ile redukcja liczby osób nic nie produkujących nie stanowi współcześnie żadnego społecznego problemu - a ich obecność jako nieużytecznych i zbędnych staje się akceptowalna ${ }^{14}$ - o tyle ograniczanie liczby konsumentów jest czynnikiem społecznie niepożądanym. Ta szczególna zewnętrzna presja przenosi się na świadomość poszczególnych osób, które przeniknięte są lękiem odnośnie do możliwości sprostania konsumenckim wyzwaniom. Te bowiem - co radykalnie eksponuje Bauman - nie ograniczają się wyłącznie do postulatu prozaicznej konsumpcji.

Chodzi bowiem o specyficzne - rodzące skutki zarówno antropologiczne (kontekst tożsamości człowieka), jak i etyczne - modyfikowanie świadomości osoby ludzkiej funkcjonującej w współczesnym zmiennym świecie; świecie pulsujacym niestabilnością i rodzącym stałą niepewność. W tym kontek-

\footnotetext{
${ }^{9}$ Tenże, Praca, konsumpcjonizm i nowi ubodzy, Kraków 2006, s. 60.

${ }^{10}$ Tamże, s. 77.

${ }^{11}$ Por. tenże, Plynne czasy, s. 120nn.

12 Tamże, s. 9.

${ }^{13}$ Por. tegoż, Praca, konsumpcjonizm i nowi ubodzy, s. 24nn.

${ }^{14}$ Por. tamże, s. $128 \mathrm{nn}$.
} 
ście Bauman zauważy, że „płynne życie, to życie oddane bez reszty konsumpcji. Traktuje ono świat oraz wszystkie jego ożywione i nieożywione elementy jak przedmioty konsumpcji, a więc przedmioty, które tracą swą użyteczność (a co za tym idzie: swój blask, atrakcyjność, siłę przyciągania i wartość) w miarę ich używania"15. Człowiek wtopiony w owo współczesne płynne życie odnosi się do całokształtu rzeczywistości w optyce syndromu konsumpcyjnego. Wszakże ,'syndrom konsumpcyjny', posiadający charakter poznawczy i wartościujący, steruje postrzeganiem - powie Bauman - i podejściem do praktycznie wszystkich elementów przestrzeni społecznej oraz inicjowanych i kształtowanych przez nią działań. [...]. To prawdziwy syndrom, zespół zróżnicowanych, ale ściśle powiązanych z sobą postaw i strategii, nastawień poznawczych, sądów wartościujących, presupozycji, sformułowanych wprost i przyjętych milcząco założeń na temat zasad rządzących światem [...], wizji szczęścia [...]"16.

Bycie konsumentem zatem wywiera wpływ na każdy element człowieczej egzystencji. Określa przecież zarówno widzenie świata jak i samego siebie. Zdaje się stanowić szczególny podmiotowy czynnik, który nieuchronnie modyfikuje indywidualne bycie $w$ świecie. Podmiotowe człowieczeństwo zredukowane do egzystencjalnego statusu bycia konsumentem $\mathrm{z}$ jednej strony wtopione jest w zewnętrzną niepewność - stanowiącą istotny wymiar współczesnej, nieustannie przekształcającej się rzeczywistości - z drugiej natomiast strony owo człowieczeństwo zdaje się podlegać wpływowi tejże niepewności. Inaczej mówiąc - transcendentna wobec podmiotu niepewność zdaje się przenikać w głąb ludzkiej natury.

Człowiek współczesny - zredukowany i redukujący się do poziomu konsumenta, a jednocześnie obawiający się popadnięcia w stan nieużyteczności świadomie przekształca siebie zgodnie z ponowoczesnym ideałem. Konstytutywnym wręcz elementem dla natury konsumenckiego człowieka jest pozbycie się immanentnych stałych momentów. $\mathrm{O}$ tyle bowiem można być człowiekiem - sprawnym konsumentem - o ile pozbędzie się jakichkolwiek trwałych sfer własnej tożsamości. Pulsujacemu zmiennością współczesnemu światu odpowiada - i to w sensie koniecznym - ciagła antropologiczna zmienność. Jakakolwiek bowiem ludzka stałość unicestwiłaby człowieka jako konsumenta. Bycie konsumentem bowiem to bycie w ciagłym ruchu i w nieustannym sukcesywnie narastającym - odrywaniu się od każdego status quo. Wszakże

\footnotetext{
${ }^{15}$ Tenże, Plynne życie, s. 17.

16 Tamże, s. 130n.
} 
„gdyby jednostki poczuły się pewnie, gdyby zadowoliły się swoim stanem posiadania [...], zadałyby tym samym śmiertelny cios rynkowi" ${ }^{17}$.

W tym kontekście można powiedzieć, że o tyle staję się człowiekiem (konsumentem), o ile jestem w stanie permanentnego niezaspokojenia i pragnę posiąść kolejny przedmiot, który z samej natury konsumenckiego świata skazany jest na - szeroko rozumiane - unicestwienie. Specyficznym imperatywem konsumenta jest brak wewnętrznego przywiązania do przedmiotu i troska o ciagłe pożądanie czegoś nowego, kolejnego i następnego. Bauman powie, że „'doskonałego konsumenta' dałoby się porównać do fabryki, która pracując [...] dwadzieścia cztery godziny na dobę przez siedem dni w tygodniu, zapewnia nieprzerwaną produkcję ulotnych, krótkotrwałych pragnień 'jednorazowego użytku"'18. Doskonały konsument - stanowiący w Baumanowskiej optyce współczesny antropologiczny ideał - byłby człowiekiem pozbawionym trwałego wewnętrznego osobowego rdzenia. Jego identyczność bowiem budowałaby się jedynie jako zestaw narastających nieustannie egzystencjalnych epizodów; epizodów, z których każdy faktycznie zamykałby się w aktualnym dążeniu do zaspokojenia tego oto (kolejnego już) pragnienia i postulowałby nastanie następnego pożąawczego epizodu.

Tak rozumiana podmiotowa identyczność jest przeniknięta fundamentalną wręcz niestabilnością. Budowana jest wszakże w kontekście nieustannego wybierania przedmiotów konsumpcji. Temu ostatniemu natomiast towarzyszy nie tylko brak pewności, iż dokonało się właściwego (słusznego!) wyboru, ale i świadomość tego, iż nie istnieje właściwy wybór! Każda wszakże decyzja człowieka-konsumenta swoje uzasadnienie posiada wyłącznie w aktualnym pożądaniu i jako taka (będąc jednocześnie skazaną na przejście w kolejny epizod konsumenckiego bycia) pozbawiona jest obiektywnego sensu. Niepewność zatem zostaje wpisana niejako w naturę człowieka i zdaje się wzrastać korelatywnie do rynkowych ofert. „Nadmiar możliwości - powie filozof - powiększa jednak dodatkowo niepewność wyboru, którą miał jeśli nie usunać, to w każdym razie złagodzić lub ograniczyć. [...] Życie konsumentów to niekończąca się seria prób i błędów. [...]. Życie konsumenta to nieustanna huśtawka nastrojów"19.

${ }^{17}$ Tamże, s. 56

${ }^{18}$ Tamże, s. 144.

${ }^{19}$ Tamże, s. 132n. „W każdej beczce zmysłowego miodu - powie Bauman w innym miejscu znajdzie się zawsze łyżka, albo i chochla, dziegciu niepewności; każdą radość z przeżytego doświadczenia truje strach przed nieadekwatnością - podejrzenie, że się nie stanęło na wysokości zadania, że nie wycisnęło się przyjemności do końca, że inni potrafiliby więcej z okazji wydobyć". Tenże, Ponowoczesność jako źródto cierpień, Warszawa 2000, s. 308. 
Bycie człowiekiem w Baumanowskich płynnych czasach oznacza de facto stan permanentnej niepewności i tworzenie kolejnego własnego epizodu w procesie konsumenckiego dziania się; procesie, który pozbawiony jest zarówno ontycznych jak i antropologicznych racji, a którego jedyny sens można odnaleźć na poziomie rozsypanej tożsamości, która redukuje się do kolejnych (stanowiących zamknięte całości) epizodycznych, konsumenckich odniesień do świata. Mówiąc metaforycznie - o tyle jestem, o ile jestem wolny od trwałego ontycznego rdzenia i doskonalę się w intensyfikacji własnego pożądania w taki sposób, aby wyzwalać się sukcesywnie z dotychczasowego pragnę tego a tego i aby móc $\mathrm{z}$ większą jeszcze mocą pragnąć nowego tego a tego; o tyle jestem - można by paradoksalnie powiedzieć - o ile mnie nie ma (jako trwałego Ja). Bauman wyraźnie skonstatuje, że ,jedynym ,jądrem tożsamościowym", które z całą pewnością wyjdzie z tej karuzeli przemian nie tylko bez szwanku, ale wręcz wzmocnione, jest homo eligens - człowiek wybierający (ale nie człowiek, który wybrał!): trwale nietrwałe ,ja”, w pełni niespełnione, ostatecznie nieostateczne i autentycznie nieautentyczne"20. Współczesny człowiek zresztą nie chce odnaleźć autentycznej własnej tożsamości. Przeniknięty immanentną epizodycznością każdego momentu własnej egzystencji i - nieuchronnie z tym związaną - niepewnością zdaje się akceptować takie antropologiczne status quo. Jego oczekiwania filozof oddaje słowami: „anulowanie przeszłości, 'narodzenie się na nowo', zdobycie nowego 'ja', odrodzenie się 'jako zupełnie inna osoba' [...] marzenie o ucieczce od własnego ja oraz przekonanie, że urzeczywistnienie tego marzenia leży w naszym zasięgu. Nie traktuje się jej jako jednej z dostępnych możliwości, ale jako najłatwiejsze rozwiązanie $[\ldots]^{21}$.

Owej ciagłej ucieczce od autentycznej osobowej tożsamości - od swego „Ja” - i ciagłemu tkwieniu w immanentnej niepewności towarzyszy zresztą transcendentna wobec człowieka niepewność. Świat zewnętrzny bowiem nie pozwala na odnalezienie jakiejkolwiek trwałości; jakiejkolwiek nie-zmiennej i nie-przemijającej sfery, która umożliwiłaby odkrycie przez osobowy byt trwałego fundamentu sensu. Świat zewnętrzny pulsuje zmiennością i uniemożliwia człowiekowi poznawcze dotknięcie bytowej racjonalności. Bauman wskaże na ,przekonanie lub podejrzenie, że nie istnieją żadne ustalone wcześniej reguły lub obrane wspólnie cele, do których dążenie uwolniłoby ludzi od niepożądanych konsekwencji ich wyborów. Punkty odniesienia i wskazówki, które dziś wydają się godne zaufania, jutro prawdopodobnie zostaną uzna-

\footnotetext{
${ }^{20}$ Tenże, Plynne życie, s. 55.

${ }^{21}$ Tenże, Szanse etyki $w$ zglobalizowanym świecie, s. 213.
} 
ne za mylące i błędne”22. Filozof zauważy również, że „drogowskazy zdają się pokazywać różne drogi; sposób bycia, jaki jeden wzór doradza lub zachwala, drugi wzór gani lub wyśmiewa. Co by więc człowiek ponowoczesny nie uczynił, nigdy nie nabierze pewności, że uczynił to, co trzeba" ${ }^{23}$. Człowiek współczesny jest zarówno sam przeniknięty niepewnością, jak również przez nią jest otoczony.

Każdy element, który mógłby stanowić regułę, aksjologiczny pewnik, normę czy jakikolwiek przejaw bytowej inteligibilności naznaczony jest nieuchronnie prze-mijaniem i wtopiony jest w nurt płynnego stawania się. Świat otaczający staje się sumą wrażeń, które mogą stanowić przedmioty naszego pożądania, a wszystko zmienia się niczym w kalejdoskopie - rzeczywistość jest nie-stałością, a podmiot odnoszący się do niej prze-chodzeniem kolejnych chwilowych pragnień. W takiej rzeczywistości uległy unicestwieniu wszelkie wartości i nośniki sensu. Nie ma też miejsca na miłość. Pozostają tylko „naskórkowe kontakty i hotelowe romanse, których urok na tym właśnie się zasadza, że jutro nadawać się już będą tylko do puchnącej z dnia na dzień teczki wspomnień" 24 . Ów stan permanentnego dynamizmu i wykluczenia z tego, co istnieje, autentycznych fundamentów racjonalności, odnaleźć można w jeszcze jednej konstatacji postmodernisty twierdzącego, że „kuszące alternatywne oferty - rozgłos zamiast normatywnych ustaleń, sezonowe sławy i jednodniowi idole, ulotni bohaterowie, których wydobywa z mroku i milczenia reflektor lub mikrofon w ręku reportera i którzy znikają ze sceny i gazetowych czołówek z prędkością błyskawicy - oto ruchome drogowskazy w świecie pozbawionym drogowskazów trwałych"25.

Bauman jednak zdaje się wskazywać na szansę odnalezienia pewnego wyjścia z wyżej opisanego antropologicznego zagubienia poprzez odkrycie szczególnej sfery tkwiącej w głębi człowieka; sfery o wymiarze moralnym. Skonstatuje bowiem, że ,jaźni przed jaźnią moralną nie ma, istnienie moralności jest 'faktem ostatecznym' i niejako pierworodnym [...]"26. W tym kontekście można by przypuszczać, że to właśnie moralność pozwoli przełamać dramat powszechnej niestabilności sensu i wskazać ponowoczesnemu człowiekowi rzetelny - nie tylko etyczny, ale wręcz ontologiczny - fundament jego egzystencji.

\footnotetext{
${ }^{22}$ Tamże, s. 225.

${ }^{23}$ Tenże, Dwa szkice o moralności ponowoczesnej, Warszawa 1994, s. 38.

${ }^{24}$ Tamże, s. 33. Por. tamże, s. 17; tenże, Etyka ponowoczesna, s. $141 \mathrm{nn}$.

${ }^{25}$ Tenże, Plynne życie, s. 52.

${ }^{26}$ Tenże, Etyka ponowoczesna, s. 22.
} 


\section{MORALNOŚĆ WOBEC BRAKU PEWNOŚCI}

Sam Bauman pokłada wiele zaufania w odrodzonej moralności. Ta ostatnia w czasach ponowoczesnych - w okresie płynnej nowoczesności - jest już wyzwolona z gorsetu nowoczesnej etyki kodeksowo-jurydycznej. Życie moralne człowieka nie jest już wtłoczone $\mathrm{w}$ ramy norm etycznych pretendujących do uniwersalnej akceptacji. Mając świadomość, że „zmierzch Wieku Etyki (a więc wieku ferowania praw dla moralności)" ${ }^{27}$ - w optyce Baumanowskiej - nie stanowi wcale kresu życia moralnego, a „kres 'ery etyki' jest początkiem 'ery moralności' [...]"28, musimy bliżej przyjrzeć się tejże wyzwolonej moralności.

Charakterystyczne dla rozważań etycznych omawianego postmodernisty jest wyeksponowanie kategorii odpowiedzialności. Zdaje się ona stanowić szczególne centrum analiz. „To właśnie podejmując się odpowiedzialności za dobro innych - powie filozof - na jaką skazany jestem już jako istota społeczna, spełniam się jako 'osoba'. Być osobą to tyle, co zdać sobie sprawę z odpowiedzialności za innych, zgodzić się na tę odpowiedzialność i uznać, że choć wszyscy jesteśmy sobie nawzajem winni odpowiedzialność, to ja i tylko ja odpowiadam za wywiązanie się ze swojej"29. Odpowiedzialności Baumanowskiej zdaje się zresztą towarzyszyć rys radykalizmu czy nawet heroizmu. Wszakże „odpowiedzialność moralna jest ze swej strony jednostronna (czy raczej obojętna wobec dwustronności), asymetryczna i nie-wzajemna (czy raczej obojętna na fakt, że będzie odwzajemniona)"30. Odpowiedzialność ma zawsze charakter indywidualnego - mojościowego - imperatywu odnoszącego się do moich relacji z innymi ludźmi. W odpowiedzialności nacisk położony jest nie tyle na interpersonalny (symetryczny) charakter, ile właśnie na mojościowe zobowiązanie wobec Innego, w które jestem po prostu uwikłany. Zawsze to Ja ponoszę odpowiedzialność i od ciężaru tejże godności nie mogę się uchronić. Imperatyw odpowiedzialności zresztą ściśle wiąże się z osobową wolnością. „Nie jesteśmy wolni. Wyzwolenie - konstatuje filozof - przychodzi dopiero wtedy, gdy decydujemy się przekuć los w powołanie; gdy, innymi słowy, przyjmujemy odpowiedzialność za tę odpowiedzialność, którą i tak wszak ponosimy i od której uwolnić się nie możemy”31.

\footnotetext{
27 Tenże, Dwa szkice o moralności ponowoczesnej, s. 73.

${ }_{28}$ Tamże, s. 83.

${ }^{29}$ Tenże, Moralność w niestabilnym świecie, s. 12.

${ }^{30}$ Tenże, Ponowoczesność jako źródło cierpień, s. 99.

${ }^{31}$ Tenże, Szanse etyki $w$ zglobalizowanym świecie, s. 357.
} 
Można by więc pokusić się o stwierdzenie, iż sfera moralna człowieka sfera związana z odpowiedzialnością za każdego Innego - nabiera zarówno wymiaru antropologicznej powszechności, jak i ontycznego fundamentu dla zagubionej ponowoczesnej tożsamości człowieka. Skoro żaden człowiek nie może wyzwolić się od decydującej dla moralności odpowiedzialności, to być może - właśnie jego przestrzeń moralna mogłaby być odczytana jako bytowy rdzeń człowieka. Element jego natury konstytutywnej; rdzeń pozwalający wyrwać się z współczesnej sieci - zarówno transcendentnej, jak immanentnej, człowieczej - permanentnej niepewności. Bauman przecież ową odpowiedzialność zdaje się osadzać bardzo głęboko w ludzkiej naturze i nadawać jej radykalny, ogólnoludzki charakter i zasięg. W owym radykalizmie idzie tak daleko, że przypisuje człowiekowi odpowiedzialność za losy każdego innego człowieka i zdaje się domagać swoistej świeckiej świętości. W kontekście refleksji skupionej wokół Lévinasa zauważy, że „standard, wedle którego ja (tylko ja) mogę mierzyć moją (tylko moją) odpowiedzialność, jest, w tym sensie, skrojony na wzór świętych: jest standardem, który mogę i winieniem nawet - stworzyć dla siebie, ale którym nie wolno mi się posłużyć dla mierzenia moralności innych"32. O zasięgu natomiast mojej odpowiedzialności może świadczyć przekonanie Baumana, że w dzisiejszej rzeczywistości odróżnienie przez Jaspersa winy moralnej (związanej z moim konkretnym działaniem) od winy metafizycznej (wynikającej $\mathrm{z}$ faktu cierpienia jakiegokolwiek człowieka) straciło swoje uzasadnienie ${ }^{33}$. W kontekście powszechności informacji i tkwienia w cyberprzestrzeni swoją odpowiedzialnością partycypuję w cierpieniu każdego człowieka. Wszakże „nikt z nas nie może się już dziś zaklinać, że nie ma żadnego związku między jego ospałością czy, przeciwnie, zapaleństwem, a huraganem nieszczęść, jakie nawiedziły odległe ludy i nadal nad nimi wiszą" 34 .

W świetle powyższych rozważań można by sądzić, iż zdołaliśmy odnaleźć w refleksji Baumanowskiej swoisty punkt oparcia dla współczesnego człowieka, który pozwoli mu odnaleźć zarówno prawdę o sobie samym jako

\footnotetext{
${ }^{32}$ Tenże, Etyka ponowoczesna, s. 71. Warto w tym miejscu nadmienić, iż Bauman czasami stosuje specyficzny styl narracji, w którym trudno zdecydowanie oddzielić referowanie poglądów innych myślicieli od jego własnych poglądów. Zbigniew Sareło - omawiając poglądy Baumana stwierdzi, że „napotykamy na trudność, którą niesie ze sobą eklektyzm jego wypowiedzi [...]. Poglądów wymienionych myślicieli Z. Bauman nie podziela w całości. Przejmuje on od nich tylko pojedyncze idee". Z. Sareło, Złożenia antropologiczne $w$ etycznych pogladach Z. Baumana, w: Moralność i etyka w ponowoczesności, red. Z. Sareło, Warszawa 1996, s. 65.

${ }^{33}$ Por. Z. Bauman, Szanse etyki w zglobalizowanym świecie, s. 66; tenże, Moralność w niestabilnym świecie, s. 14.

${ }^{34}$ Tenże, Moralność w niestabilnym świecie, s. 15.
} 
człowieku - a także tym oto człowieku - jak i wyciszyć ciagłą niepewność; punkt oparcia, którym byłaby przestrzeń moralna konstytuowana przez mojościowa odpowiedzialność. Baumanowska etyka jednak obejmuje także takie momenty, które zdają się podważać taką ewentualność.

Już na wstępie do swojej klasycznej już Etyki ponowoczesnej filozof stwierdzi, że „ludzie są moralnie wieloznaczni: ambiwalencja unosi się nad 'pierwotną sceną' ludzkiego spotkania. [...] moralność nieambiwalentna jest egzystencjalnie niemożliwa" ${ }^{35}$. Odnajdujemy tam także twierdzenie, że „,moralność jest nieuleczalnie aporetyczna. Nieliczne tylko wybory (i to z reguły wybory trywialne...) są jednoznacznie dobre. W większości przypadków wybierać trzeba między sprzecznymi impulsami. Co gorsza, każdy niemal impuls moralny, jeśli podporządkować mu się bez reszty, doprowadzić może do niedobrych następstw (przykładem najbardziej dobitnym jest impuls troski i opieki nad Drugim Człowiekiem - który, doprowadzony do krańca, wiedzie do unicestwienia autonomii podmiotowej podopiecznego, do zdominowania jego osobowości, do ucisku)" "36. Wydaje się, że te Baumanowskie wglądy w specyfikę jego moralności oddają najbardziej istotne jej momenty. Przestrzeń moralna przenikająca naturę pojedynczego człowieka - przestrzeń, w której próbowaliśmy doszukać się antropologicznego, ale i ontycznego rdzenia pozwalającego usunąć immanentny niepokój - pozbawiona jest jednoznaczności i czytelności.

Bauman wszakże wprost przypisuje jej zarówno ambiwalencję jak i aporetyczność. To, co zdawało się stanowić szansę na odrodzenie człowieka płynnej nowoczesności - na odnalezienie jego zagubionej (zarówno gatunkowej jak i indywidualnej) tożsamości - samo zdaje się stanowić źródło niepokoju. Skoro bowiem wspomniana sfera moralna sama jest ogołocona z trwałego sensu i wyklucza odnalezienie w sobie ostatecznego ładu i uporządkowania, to trudno ją uznać za poszukiwany przez Baumana - przynajmniej implicite, tzn. w kontekście eksponowania współczesnej zmienności - drogowskaz dla współczesnego człowieka. Bauman stawia człowiekowi poszukującemu własnej wolności i dążącemu do bycia pełną osobą wysokie standardy oczekiwań (absolutna odpowiedzialność za Innych granicząca wręcz ze świętością), ale jednocześnie cała etyczna doktryna filozofa zdaje się ograniczać tylko do tego postulatu. Bauman obciąża człowieka koniecznością wzięcia odpowiedzialności, lecz pozostawia go zupełnie samego wobec zarówno wyjaśnienia konieczności pójścia drogą świeckiego świętego, jak również

\footnotetext{
${ }^{35}$ Tenże, Etyka ponowoczesna, s. $17 \mathrm{n}$

${ }^{36}$ Tamże, s. 19.
} 
sposobu realizacji owego wzniosłego postulatu. Jedyny drogowskaz dla poszczególnego człowieka tkwi wyłącznie w nim samym w formie jego indywidualnej moralności; w postaci jego (wyłącznie jego!) osobowych impulsów moralnych, dla których nie można odnaleźć żadnych ogólnych normatywnych wskazówek.

Bauman wprowadza mojościowa egzystencję w stan osamotnienia i konieczności sprostania imperatywowi moralnej odpowiedzialności za losy wszystkich ludzi oraz zmusza ją do odnalezienia sposobów realizacji tegoż zadania wyłącznie w sobie. Filozof obwieściwszy zmierzch wieku etyki (kodeksowej, normatywnej) - przekreśliwszy sens obecności jakichkolwiek trwałych moralnych zasad - odkrytą przez siebie moralność zdaje się utożsamiać tylko z indywidualnością impulsów moralnych. Te natomiast zupełnie wyzwolone z ogólnych norm stają się zarówno ambiwalentne jak i aporetyczne. Moralność jest wprawdzie mojościowa - wreszcie wolna od deprecjonowanych przez Baumana norm - ale równocześnie jest nie-do-precyzowana, radykalnie nieokreślona. W jej naturę wpisana jest nieusuwalna sprzeczność. Przecież moralny impuls może zrodzić ucisk Drugiego i panowanie nad nim; przecież ,z tej samej gleby wyrastają miłość i nienawiść; najbardziej człowiecza z miłości i najbardziej nieludzka z nienawiści. Teren odpowiedzialności jest zarazem - i to w sposób trudny do uniknięcia - polem uprawnym przemocy i okrucieństwa" 37 ; przecież „działanie moralne jest z natury wieloznaczne; balansuje ono na cieniutkiej i wyboistej ścieżce między przepaścią dominacji, z jednej strony, a otchłanią obojętności (przebranej za tolerancję) z drugiej. [...] Osoba moralna nie może przezwyciężyć ambiwalencji zawartej w jej kondycji. [...] Sztuka moralności [...] może być tylko sztuką życia i działania w warunkach wieloznacznych" ${ }^{38}$.

Wypowiedzi te wyraźnie wskazują na negatywny charakter Baumanowskiej koncepcji moralności. Wszakże moralność sama z siebie nie posiada aksjologicznej pozytywnej treści. Skoro moralne odniesienie do Drugiego doprowadzić może zarówno do jego uprzedmiotawiającej degradacji (do dominacji nad nim), jak również może przybrać postać nienawiści, to trudno znaleźć w intymności mojościowej moralnej przestrzeni źródło dobra; skoro odpowiedzialność - Baumanowski rdzeń jego moralności - doprowadzić może do okrucieństwa, to powstaje przypuszczenie, że moralny impuls sam w sobie pozbawiony jest aksjologicznego określenia, a wyłonić może nie tylko dobro, ale i zło!

${ }^{37}$ Tamże, s. 119.

${ }^{38}$ Tamże, s. 246n. 
Jeżeli jednak nasze uwagi byłaby uzasadnione twierdzeniami Baumana, to jego moralność miałaby wyraźnie znamię przed-moralne. Bez względu na to, czy posłużymy się pojęciem impulsu moralnego, osoby moralnej, jaźni moralnej czy odpowiedzialności, to sfera moralna $\mathrm{z}$ własnej natury jest przeddobrem i przed-złem. Jako taka jest potencjalnością i indywidualnością, ale z pewnością pozbawiona jest wartościowej gęstości. Przypisanie jej aporetyczności i ambiwalencji (a także irracjonalizmu ${ }^{39}$ ) zdaje się stanowić tylko Baumanowską próbę obrony owej moralności przed unicestwieniem! Owa wieloznaczność stanowi bowiem jedyne treściowe znamię. Odebranie tego momentu sprawiłoby, że moralność fundamentalnie specyfikująca każdego człowieka - ,jaźni przed jaźnią moralną nie ma" ${ }^{40}$ - przestałaby istnieć!

Analiza Baumanowskiej koncepcji moralności pozostawia nas wobec wielu pytań. Wiedząc, czym moralność nie jest - jej naturę przecież Bauman buduje poprzez konsekwentną opozycję wobec etyki normatywnej - nie możemy sprecyzować, czym ona faktycznie jest. Powszechność występowania (obecność w każdym człowieku) i wysokie standardy stawiane przed nią nie usuwają wcale wątpliwości. Baumanowskie konstatacje zdają się zresztą często pozostawać tylko na poziomie deklaracji. W tej przecież tonacji sformułowano twierdzenia, że „moja odpowiedzialność jest jedyną 'racją' działania moralnego" ${ }^{41}$, „etyka [...] ma do czynienia ze stanami, które jeszcze nie zaistniały, [...] obiektem jej troski jest przyszłość [...]" "42, jak również konstatację, iż „ludzie wrzuceni w społeczeństwo ponowoczesne nie mają poniekąd ucieczki: muszą oni spojrzeć w oczy własnej niezawisłości moralnej, a zatem własnej, nie wywłaszczalnej i nie zbywalnej, moralnej odpowiedzialności”"43. Przytoczone jednak - podniosłe i postulatywne - sformułowania nie przybliżają nas jednak do zrozumienia istoty moralności i pozostawiają nas wobec tego nie-jasne, nie-racjonalne, nie-określone i nie-dające się poznać.

Wydaje się zresztą, że to właśnie owe negatywne deskrypcje najpełniej oddają naturę Baumanowskiej koncepcji. Wszakże „nie ma więc standardów uniwersalnych, gdy o moralność idzie [...]. Moralność jest 'nieugruntowana'; moralność nie ma 'fundamentu' [...]"44. Pozostaje czystą wieloznacznościa, odarta z jakiegokolwiek ogólności i tkwiącą w normatywnej pustce; pustce, która pozbawiona fundamentu, sama ma stać się fundamentem dla odpowie-

\footnotetext{
${ }^{39}$ Por. tamże, s. 21.

40 Tamże, s. 22.

${ }^{41}$ Tamże, s. 166.

${ }^{42}$ Tamże, s. 300.

${ }^{43}$ Tenże, Dwa szkice, s. 84.

${ }^{44}$ Tenże, Etyka ponowoczesna, s. 73, 99.
} 
dzialnego bycia dla Drugiego. Ale taka pustka nie może stanowić poszukiwanej przez nas w refleksji filozofa antropologicznej rdzennej sfery, która umożliwiłaby ponowoczesnemu człowiekowi powrót do rzetelnej prawdy o sobie samym. Wręcz odwrotnie - wyzwolona moralność stanowić może źródło jeszcze większej niepewności. Skoro moralność jest czymś wcześniejszym od naszego myślenia (,jestem istotą moralną, zanim myślę" ${ }^{45}$ ), to niepewność wiążąca się z nią jeszcze intensywniej przenika naturę człowieka i pogłębia faktyczny antropologiczny dramat. Bauman pozostawia człowieka w absolutnej niepewności! Twierdzi, że „nie mogę ukoić sumienia, nie mogę uzyskać pewności poprzez stosowanie się do czytelnych reguł [...]. Choć jako istota społeczna jestem zawsze z innymi, jako istota moralna jestem zawsze sam" ${ }^{46}$. W podobnym tonie skonstatuje także, że „oszołomiona i zdezorientowana jaźń staje dziś samotnie w obliczu dylematów moralnych pozbawionych dobrego (a tym bardziej: oczywistego) wyjścia, konfliktów moralnych nie do rozwiązania i konstatacji, że być istotą moralną jest boleśnie trudno" "47. Bauman zatem de facto skazuje człowieka na nieusuwalną samotność, dramat i brak rozeznania w horyzoncie tego, co najbardziej człowiecze - aksjologicznego imperatywu!

Wydaje się jednak, iż u Baumana możemy dostrzec jeszcze głębszy i bardziej podstawowy fundament eksponowanej dotąd niepewności etycznej i antropologicznej.

\section{BYTOWA NIESTABILNOŚĆ}

„Egzystencjalne wstrząsy - zauważa Bauman - towarzyszyły ludziom na przestrzeni całej ich historii [...]. 'Los' z definicji uderza bez ostrzeżenia i bez względu na to, co jego ofiary mogą zrobić $[\ldots]^{\prime 48}$. W innym miejscu filozof stwierdzi, że „nagłość podmuchu losu, ich nieregularność [...] - wszystko to czyni je nieprzewidywalnymi, a nas samych w ich obliczu bezbronnymi. [...]. Nic dziwnego, że marzy nam się od czasu do czasu świat bez wypadków. Świat regularny, przewidywalny"49. To marzenie jednak jest nieosiagalne. Egzystencja człowieka wtopiona jest w rzeczywistość nie-regularną i nie-przewidywalną. Taka przecież autorska wizja ujawnia się de facto

${ }^{45}$ Tamże, s. 83.

46 Tamże.

47 Tamże, s. 339.

${ }^{48}$ Tenże, Plynne czasy, s. 19.

${ }^{49}$ Tamże, s. $131 \mathrm{n}$. 
w specyficznych Baumanowskich opisach, w których filozof często kryje swoje stanowisko za poglądami innych. Zauważy, że ,jako gracz, świat zachowuje się dokładnie tak samo, jak inni gracze: trzyma karty przy piersi i lubuje się w wyjściach zaskakujących i zbijających z pantałyku"50. Pomimo ascezy wobec osobistych konstatacji ontologicznych napotykamy jednak na przyznanie Baumana, że ,wiemy dziś, że nie odkryto dotąd i zapewne nie odkryje się już nigdy fundamentów bytu [...]" ${ }^{51}$, jak również, że „byt z pozoru uładzony i sensowny podszyty jest Chaosem i Absurdem [...]" ${ }^{52}$; napotykamy także na stwierdzenie, iż śmierć jest ,szparą, przez którą [...] absurdalność bytu sączy się w nurt żywota [...]"53.

Wypowiedzi te $\mathrm{z}$ jednej strony stanowią wyraz określonej ontologicznej koncepcji polskiego postmodernisty, a z drugiej - jak się zdaje - pozwalają głębiej spojrzeć na tytułową dla naszych rozważań niepewność Baumanowskiej antropologii i etyki. Okazuje się bowiem, iż omawiany filozof w swojej obszernej spuściźnie - osadzonej w socjologizujący i nieco kryjący pełnię własnych poglądów narracyjny schemat - porusza się w horyzoncie niestabilności ontycznej. Ta ostatnia stanowi trwały (aczkolwiek wprost przez autora nie ujawniany) motyw jego rozważań. Te bowiem dokonują się niejako w tle bytowego chaosu. Nie jest tak, aby tylko etyka i antropologia przeniknięte były niepewnością. To sama rzeczywistość jest absurdalna i chaotyczna. Pulsuje niestabilnością i zmiennością, a niepewność i zagubienie współczesnego człowieka stanowią tylko szczególną egzemplifikację bytowej wieloznaczności i sprzeczności. To byt sam w sobie jest tkany przez absurdalności. Ogołocony jest z trwałości, sensu i racjonalności!

Być może zatem właśnie tutaj należałoby doszukiwać się typowo Baumanowskiej - fundamentalnej i radykalnej! - niechęci do nowoczesnych projektów racjonalizacji ludzkiej rzeczywistości i jego awersji wobec etyki normatywnej. Skoro bowiem rzeczywistość jest chaotyczna, to nowoczesna pasja normatywno-jurydyczna (stanowiąca zresztą bardziej autorski wytwór redukcji kilkuwiekowej refleksji etycznej niż rzetelny opis tejże refleksji) byłaby czymś negatywnym nie tyle $\mathrm{z}$ powodu zamknięcia moralności w gorsecie zasad i norm, ile $\mathrm{z}$ powodu niezgodności z samą naturą bytu! Bauman nie opisuje takiego kontekstu, jednak - jak się zdaje - to on faktycznie określa jego refleksję etyczną i antropologiczną. Jeżeli wszakże istnienie jako takie

\footnotetext{
${ }^{50}$ Tenże, Ponowoczesność jako źródło cierpień, s. 219.

${ }^{51}$ Tenże, Dwa szkice o moralności ponowoczesnej, s. 50n.

${ }^{52}$ Tamże, s. 57.

${ }^{53}$ Tamże, s. 48.
} 
jest chaotyczne, absurdalne i nie-racjonalne, to trudno przypuszczać, aby pewne istniejące konkretne jestestwo (człowiek wraz z jego najgłębszym moralnym poziomem) pozbawione było niestabilności, irracjonalizmu i niepewności. Skoro byt jest aporetyczny, to można już spokojnie skonstatować, że „nie ma prawdziwych ani fałszywych wartości: są tylko przyjęte lub odrzucone" ${ }^{54}$.

Jeżeli jednak Baumanowskie rozważania odsłaniają powszechność irracjonalizmu - ontyczna, antropologiczną i moralną - to powstaje pytanie o sens odpowiedzialności moralnej; o sens podstawowej kategorii etycznej. Jakie jest miejsce na wzniosłość moralnego imperatywu w obliczu ontycznego Absurdu i Chaosu? Być może jest on - jako obecny w każdym człowieku stan potencjalności pozbawiony racjonalnego zakorzenienia i wytłumaczenia - jedynie wyrazem ludzkiej irracjonalnej egzystencji! Być może radykalna niepowtarzalność i mojościowość impulsów moralnych stanowi jedynie wyraz irracjonalnej natury człowieka; wyraz tego, co można by określić jako „ludzką kondycję moralną, wspólną istotom ludzkim [...]”55.

Czy jednak taka - tylko deklaratywnie wzniosła - człowiecza kondycja nie redukuje się do poziomu bliskiego specyfikacji czysto biologicznej? Bauman przecież - tym razem już wprost - postuluje „wprowadzenie do 'programu emancypacji' [...] połączenia nakazów etycznych $\mathrm{z}$ instynktem samozachowawczym w celu stworzenia swoistej wspólnoty przetrwania [...]" ${ }^{\prime 56}$. Czy tym samym jednak nie instrumentalizuje moralności i - wbrew własnym twierdzeniom - nie przypisuje jej utylitarnej i biologicznej funkcji? Może powstać bowiem podejrzenie, że ogólnoludzkie impulsy moralne nieco prozaicznie integrują ludzi ze sobą i wtapiaja się w horyzont gatunkowych mechanizmów obronnych. Trafność sugestii o naturalizacji - pozornie wzniosłej - Baumanowskiej moralności zdaje się zresztą potwierdzać szczególna estyma filozofa do ludzkości. Wszakże „moje osobiste niepowodzenia w niczym nie podważają przeświadczenia o nieskończoności ludzkiej potencji; przeciwnie, dowodzą pośrednio potęgi ludzkich, gatunkowych dokonań. Mój los uczyniło niepewnym połączenie mojej osobistej słabości i ignorancji z wszechpotęgą i wszechwiedzą ludzkiego gatunku" 57 .

Czyżby zatem powrót do autorytetu Marksa, Lenina i Róży Luksemburg nie był przypadkowy i czy nie tam właśnie należałoby szukać fundamentów myśli samego Baumana? ${ }^{58}$

${ }^{54}$ Tenże, Plynne życie, s. 166.

${ }_{55}$ Tenże, Etyka ponowoczesna, s. 23.

${ }^{56}$ Tenże, Plynne życie, s. 236.

57 Tenże, Ponowoczesność jako źródło cierpień, s. 304n.

${ }^{58}$ Por. tenże, Plynne czasy, s. 43n; tenże, Plynne życie, s. 47n, 62, 71, 217n, 223, 228, 230nn. 


\section{SUMMARY}

The article centers around Bauman's category of uncertainty and presents its ethical and anthropological contexts. The author also makes an attempt to set human drama in onthological sphere. Post-modern man is deprived of solid moral indicators and has constant doubts about the rightness of his choices. Ethical-anthropological uncertainty is a sign of onthological instability and it seems to be the consequence of absurd and irrationality immanent to Bauman's structure of being. Polish post-modernist does not say much explicite about being which is undoubtedly aporetical.

\section{Key words:}

Zygmunt Bauman, uncertainty, instability, ambivalence, globalization, consumption, responsibility 